\title{
Evaluation of Complaints Reflected to Medical Chamber of Bursa Honor Board: 1995-2005
}

\section{Bursa Tabip Odası Onur Kuruluna Yansıyan Şikayetlerin Değerlendirilmesi: 1995-2005}

\author{
Sezer Erer Kafa', \Ayşegül Demirhan Erdemir² \\ 'Bursa Uludağ University, Faculty of Medicine, Department of History of Medicine and Medical Ethics, Bursa, Türkiye \\ ${ }^{2}$ Maltepe University, Faculty of Medicine, Department of History of Medicine and Medical Ethics, Istanbul, Türkiye
}

\begin{abstract}
Aim: To evaluate the complaints in the honor board files of a medical chamber which has an important place in determining the disruptions and violations experienced in the healthcare delivery system.
\end{abstract}

Material and Method: The study is of cross-sectional type and the files reflected in the Bursa Medical Chamber Honor Board files between the years 1995-2005 were analyzed by archive analysis method.

Results: It was found that $89 \%$ of the 121 cases obtained from the 111 files examined consisted of behaviors contrary to Turkish Medical Association Laws/decisions. The reasons for the complaints in the files were listed under three main headings and the Bursa Medical Chamber Administrative Board made the highest number of complaints with $46.3 \%$. It was determined that $67.5 \%$ of the physicians who caused the complaint worked in a private institution and $67.6 \%$ were specialists. General surgery and gynecology and obstetrics took place in the top 2 places of specialization. A statistically significant relationship was found between the causes of complaints and age. It's found that fines were given at the highest rate. 27 of the 42 files submitted to the Turkish Medical Association High Honor Board are due to complaints of violation of the laws/decisions of Turkish Medical Association.

Conclusion: Evaluation of the complaints reflected in the medical chambers, which have an important place in the disciplinary process, is important for professional ethics and determining the place of deontology and medical ethics in medical education.

Keywords: Medical chamber, honor board, investigation/ prosecution, professional ethics
Öz

Amaç: Sağlık hizmet sunumu sisteminde yaşanan aksaklıkların ve ihlallerin belirlenmesinde tabip odası onur kurulu dosyalarındaki şikayetleri değerlendirmektir.

Gereç ve Yöntem: Çalışma kesitsel tipte olup 1995-2005 yılları arasında Bursa Tabip Odası Onur Kurulu dosyalarına yansıyan şikayetler arşiv inceleme yöntemi ile analiz edilmiştir.

Bulgular: İncelenen 111 dosyadan elde edilen 121 olgunun \%89'unun Türk Tabipleri Birliği Yasa/kararlarına aykırı davranışlardan oluştuğu bulunmuştur. Dosyalardaki şikayet nedenleri üç ana başlıkta yer almış ve en fazla şikayeti \%46,3 ile Bursa Tabip Odası Yönetim Kurulu yapmıştır. Şikayete neden olan hekimlerin \%67,5'inin özel kurumda çalıştığı ve \%67,6'sının uzman olduğu saptanmıştır. Uzmanlık alanlarında ilk 2 sırada genel cerrahi ve kadın hastalıkları ve doğum yer almıştır. Şikayet nedenleri ile yaş arasında istatistiksel anlamlı bir ilişki bulunmuştur. Dosyalarda en fazla oranda para cezası verilmiştir. Türk Tabipleri Birliği Yüksek Onur Kurulu'na iletilen 42 dosyanın 27'si Türk Tabipleri Birliği yasa/kararlarına aykırı davranış şikayet nedeniyledir.

Sonuç: Disiplin sürecinde önemli bir yere sahip olan tabip odalarına yansıyan şikayetlerin değerlendirilmesi, hem meslek ahlakı hem de eğitimde deontoloji ve tıp etiğinin yerini belirlemek açısından önemlidir.

Anahtar Kelimeler:Tabip odası, onur kurulu, soruşturma/kovuşturma, meslek ahlakı

Corresponding (illetişim): Sezer ERER KAFA, Assistant Professor, PhD, Bursa Uludağ University Faculty of Medicine, Department of History of Medicine and Medical Ethics, Bursa, Türkiye

E-mail (E-posta): sezer@uludag.edu.tr

Received (Geliș Tarihi): 12.11.2021Ａccepted (Kabul Tarihi): 18.12.2021 


\section{INTRODUCTION}

Professional associations began to be established with getting together of professional members to discuss common ideas and problems and the effects of the new scientific thought movement in the $19^{\text {th }}$ century. As in many professions, physicians also started to come together and organize. Following "Cemiyet-i Tıbbiye-i Şahane" (Société Impériale de Médecine de Constantinople), which was established for the first time in 1856 for the acquaintance and solidarity between the physicians of the allied armies in the Ottoman period, the first association established by Turkish physicians in 1867 was "Cemiyet-i Tıbbiye-i Osmaniye".[1-4] The first association that brought together the members of the health team was the Medical Chambers (Etıbba Odaları), which were established in accordance with the $14^{\text {th }}$ article of the law dated 11.04.1928 and numbered 1219. Reasons such as the rapid increase in the number of chamber members, the increase in professional ethics problems and the impropriety in the elections revealed the necessity for the medical chambers to become a union, and a draft regulation was prepared in 1947. In order to "... protect professional deontology and solidarity among physicians and the rights and benefits of profession members..." under constitutional guarantee, it was decided to establish 23 medical chambers at the grand congress of the "Turkish Medical Association (TMA)", which was established on 23.01.1953, and Bursa Medical Chamber (BMC) was the third. ${ }^{[1,5-9]}$

The Turkish Medical Association (TMA) and Medical Chambers, which work on basic issues such as ensuring professional discipline, investigating patient complaints and determining private wage scales, apply the principles of the disciplinary regulation to investigate the unethical behaviors of physicians during their professional practices and communication with their colleagues and to determine the disciplinary penalties to be imposed. ${ }^{[10]}$ If there is an objection to the decision after the decision given by the Honor Board is notified, the file is forwarded to the TMA High Honor Board (TMA HHB). After reviewing the investigation and prosecution files sent to it, the TMA HHB sends its decision to the Medical Chamber with a re-decision to approve or overturn the decision.

The studies conducted with the complaints/files of the medical chambers, which have an effective mechanism for the protection/observance of the rules of professional ethics, provided important data specific to the city and the region. ${ }^{[11-}$ ${ }^{14]}$ In this context, it is aimed to evaluate the complaints in the Bursa Medical Chamber Honor Board files.

\section{MATERIAL AND METHOD}

The study was cross-sectional and retrospective. The files sent to the Honor Board by the BMC Administrative Board between 1995 and 2005 were scanned with the archive analysis method to create the data of the research, and a total of 111 files were evaluated.
The files were classified with the "file evaluation form" created by the researchers and the basic data of the study were obtained. The sociodemographic characteristics of physicians (age, gender, institution/organization where they work, specialty), complainant, cause of complaint, year of complaint, punishment recommended by the honor board, objection to the punishment given, transmission to YOK, decision-making time were questioned and the data set was obtained by querying the form.

The study was approved by the local ethics committee in Uludağ University Faculty of Medicine Medical Research Ethics Committee with a decision number 2005-7/13. All procedures were carried out in accordance with the ethical rules and the principles of the Declaration of Helsinki.

Statistical Analysis: The results were presented as mean \pm standard deviation or median (minimum-maximum) for continuous variables. Categorical variables were described as frequency and percentage. Shapiro Wilk test was used as normality test. One-way ANOVA and Kruskal Wallis tests were used for comparisons between groups. Pearson Chisquare, Fisher-Freeman-Halton and Fisher's Exact Chi-square tests were used in the analysis of categorical data. In case of significance between the groups, Bonferroni test, one of the multiple comparison tests, was used for pairwise comparisons. A p-value $<0.05$ was considered as significant. All statistical analyses were performed with IBM SPSS ver.23.0 (IBM Corp. Released 2015. IBM SPSS Statistics for Windows, Version 23.0. Armonk, NY: IBM Corp.).

\section{RESULTS}

A total of 121 cases were evaluated because each physician in the 111 files referred to the BMC Honor Board (BMC HB) between 1995 and 2005 was considered a different case. There were 97 physicians, 89 men and 8 women, in the cases forming the research data. There are 7 files with more than one physician in the files and 13 physicians partaken in more than one file were determined. One of the files is about the BMC Administrative Board, and a total of 120 physicians were evaluated.

It was found that $89.2 \%(n=107)$ of the physicians in the cases were male and $10.8 \%(n=13)$ were female; the average age of male physicians was $41.5 \pm 9.7$ years, and $48.7 \pm 18.2$ of female physicians. Considering the cases with workplaces, $32.5 \%$ $(n=38)$ were in public institutions and $67.5 \%(n=79)$ were in the private sector; $67.6 \%(n=75)$ of the physicians were determined as specialists and $32.4 \%(n=36)$ as general practitioners. Of $28(37.3 \%)$ physicians have a specialty in internal sciences and $47(62.7 \%)$ in surgical sciences (Table 1). While there was no statistically significant difference between the areas of specialization and the gender distribution, a statistically significant difference was found between the gender distributions according to the workplaces. While there was no statistical significance between the areas of specialization and the gender distribution, a statistically significant difference 
was found between the gender distributions according to the workplaces ( $p=0.009$, Table 2 ). It was determined that the reason for this significant difference was that all of the female physicians included in the complaint files were working in the private sector.

\begin{tabular}{|c|c|c|c|}
\hline \multicolumn{2}{|c|}{ Specialties } & \multirow{2}{*}{$\begin{array}{c}\mathbf{n} \\
11\end{array}$} & \multirow{2}{*}{$\begin{array}{c}\% \\
14.7\end{array}$} \\
\hline \multirow{10}{*}{ 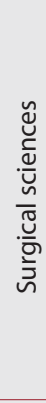 } & General surgery & & \\
\hline & Gynecology and obstetrics & 11 & 14.7 \\
\hline & Cardiovascular surgery & 7 & 9.3 \\
\hline & Otorhinolaryngology & 6 & 8 \\
\hline & Ophthalmology & 4 & 5.3 \\
\hline & Urology & 2 & 2.7 \\
\hline & Orthopedics and traumatology & 2 & 2.7 \\
\hline & Plastic and reconstructive surgery & 2 & 2.7 \\
\hline & Neurosurgery & 1 & 1.3 \\
\hline & Anesthesiology & 1 & 1.3 \\
\hline \multirow{11}{*}{ 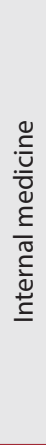 } & Pediatrics & 5 & 6.7 \\
\hline & Internal diseases & 4 & 5.3 \\
\hline & Cardiology & 4 & 5.3 \\
\hline & Microbiology and infectious diseases & 3 & 4 \\
\hline & Radiology & 3 & 4 \\
\hline & Dermatology & 3 & 4 \\
\hline & Public health & 2 & 2.7 \\
\hline & Radiation oncology & 1 & 1.3 \\
\hline & Physical medicine and rehabilitation & 1 & 1.3 \\
\hline & Psychiatry & 1 & 1.3 \\
\hline & Rheumatology & 1 & 1.3 \\
\hline
\end{tabular}

\begin{tabular}{llccc}
\multicolumn{5}{l}{ Table 2. Distribution of occupational characteristics by gender } \\
\hline & & Male (n - \%) & Female (n - \%) & p \\
\hline \multirow{4}{*}{ Specialty } & Internal medicine & $26(25 \%)$ & $2(28.6 \%)$ & \\
& Surgical sciences & $44(42.3 \%)$ & $3(42.9 \%)$ & 1.000 \\
& General practitioner & $34(32.7 \%)$ & $2(28.6 \%)$ & \\
\hline \multirow{2}{*}{ Work } & Public & $38(36.2 \%)$ & $0(0 \%)$ & \multirow{2}{*}{0.009} \\
& Special & $67(63.8 \%)$ & $12(100 \%)$ & \\
\hline
\end{tabular}

When the complainants in the files were examined, it was determined that the BMC Administrative Board (46.3\%, $\mathrm{n}=56)$ and physicians $(20.7 \%, \mathrm{n}=25)$ made the most complaints (Figure 1).

The causes of complaints in the determined cases are classified under 3 main headings: Behaviors contrary to the TMA Law/ decisions, behaviors contrary to deontology and behaviors contrary to medical ethics. The cases were mostly included under the heading of behaviors contrary to the TMA Law/ decisions (Figure 2). It was observed that, the highest rate of "promotion for advertising purposes" (40.5\%) under the heading of acts contrary to the TMA Law/decisions; "behaving humiliating a colleague" (2.5\%) under the title of behaviors contrary to deontology and "medical error and negligence" $(5 \%)$ under the title of behaviors contrary to medical ethics (Table 3).

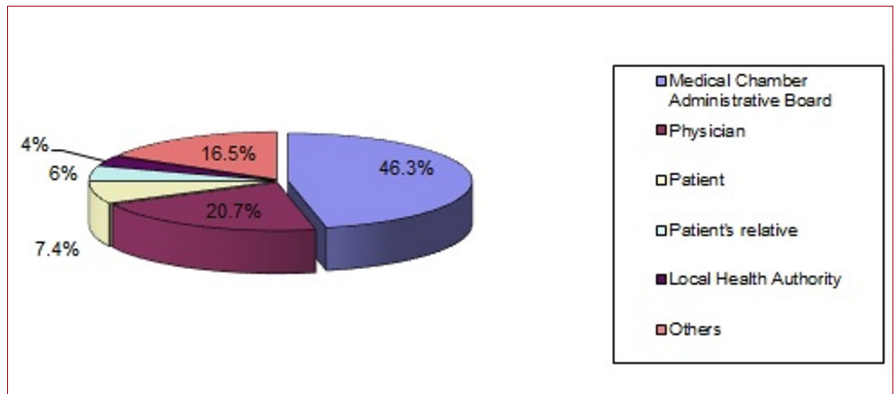

Figure 1. Complainants in cases

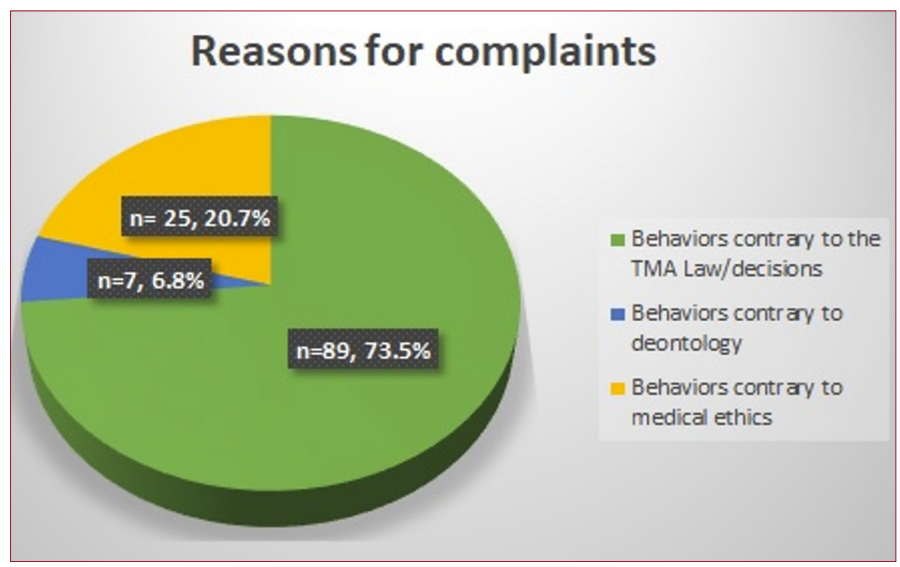

Figure 2. Reasons for complaints

Table 3. Distribution of the causes of complaints in the files of BMC Honor Board

\begin{tabular}{|c|c|c|c|}
\hline \multicolumn{2}{|c|}{ Causes of complaints } & $\mathbf{n}$ & $\%$ \\
\hline \multirow{7}{*}{$\begin{array}{l}\text { Behaviors } \\
\text { contrary to } \\
\text { the Turkish } \\
\text { Medical } \\
\text { Association } \\
\text { Law/ } \\
\text { decisions }\end{array}$} & Not to pay membership fee & 11 & 9.1 \\
\hline & $\begin{array}{l}\text { Not to register / notice to the medical } \\
\text { chamber }\end{array}$ & 7 & 5.8 \\
\hline & $\begin{array}{l}\text { Not meeting the requirements as } \\
\text { occupational physician }\end{array}$ & 4 & 3.3 \\
\hline & $\begin{array}{l}\text { Making promotion for advertising } \\
\text { purposes }\end{array}$ & 49 & 40.5 \\
\hline & $\begin{array}{l}\text { Working below the minimum } \\
\text { examination fee }\end{array}$ & 16 & 13.2 \\
\hline & Making signboard irregularities & 2 & 1.7 \\
\hline & Writing irregular prescription & 2 & 1.7 \\
\hline \multirow{2}{*}{$\begin{array}{l}\text { Behaviors } \\
\text { contrary to } \\
\text { deontology }\end{array}$} & Behaving humiliating a colleague & 3 & 2.5 \\
\hline & $\begin{array}{l}\text { Offending the dignity of medical } \\
\text { profession }\end{array}$ & 1 & 0.8 \\
\hline \multirow{10}{*}{$\begin{array}{l}\text { Behaviors } \\
\text { contrary } \\
\text { to medical } \\
\text { ethics }\end{array}$} & Not showing respect for life and health & 2 & 1.7 \\
\hline & Medical error and negligence & 6 & 5 \\
\hline & $\begin{array}{l}\text { Lack of knowledge and skills in the } \\
\text { profession }\end{array}$ & 4 & 3.3 \\
\hline & Unprofessional activities & 4 & 3.3 \\
\hline & Illegal termination of pregnancy & 2 & 1.7 \\
\hline & Unfair advantage & 4 & 3.3 \\
\hline & Allowing illegal medical intervention & 1 & 0.8 \\
\hline & Preparing false documents & 1 & 0.8 \\
\hline & Revealing patient's secret & 1 & 0.8 \\
\hline & $\begin{array}{l}\text { Writing green' prescription for } \\
\text { misconduct }\end{array}$ & 1 & 0.8 \\
\hline
\end{tabular}


When the distribution of the complaints in the cases according to the years was examined, it was found that the most complaints were between 1995 and 1999. While there was no statistically significant difference between the causes of complaints and the year distribution, it was found that the most complaints between 1995 and 1999 were behaviors contrary to the TMA Law/decisions (Figure 3). When the causes of complaints were examined in terms of sociodemographic characteristics, there was no statistically significant difference between gender, specialty and workplace, while the mean age of the physicians who acts contrary to the TMA Law/decisions was $(39.5 \pm 8.6$ years) significantly lower than the physicians who behaves contrary to deontology (51.2 \pm 12.4 years) and physicians who behaviors contrary to medical ethics $(46.7 \pm 11.9$ years) $(\mathrm{p}=0.001)$.

When the complainants and the causes of complaints were examined, it was found that the BMC Administrative Board (89.3\%) and physicians (72\%) complained about the behavior contrary to the TMA law / decisions, while the patients and patients' relatives $(93.3 \%$ ) complained about the behavior of the physicians contrary to medical ethics ( $p=0.001$, Table 4). When the BMC HB decisions are examined, it is seen that $94.4 \%$ $(n=68)$ of the physicians who were complained for behaviors contrary to the TMA Law/decisions received fines; $18.2 \%$ $(n=2)$ of the physicians who were complained for behaviors contrary to deontology received a warning penalty; $58.4 \%$ $(n=6)$ of the physicians who were complained for behaviors contrary to medical ethics were not deemed necessary to be punished $(p<0.001)$. When 42 cases transmitted to TMA HHB were examined, it was seen that $81.8 \%(n=27)$ of the files forwarded with the physician's objection against decision were due to behaviors contrary to the TMA Law/decisions $(p=0.005)$. It was determined that $51.3 \%(n=20)$ of the cases transmitted to TMA HHB ended with a fine $(p=0.048)$.

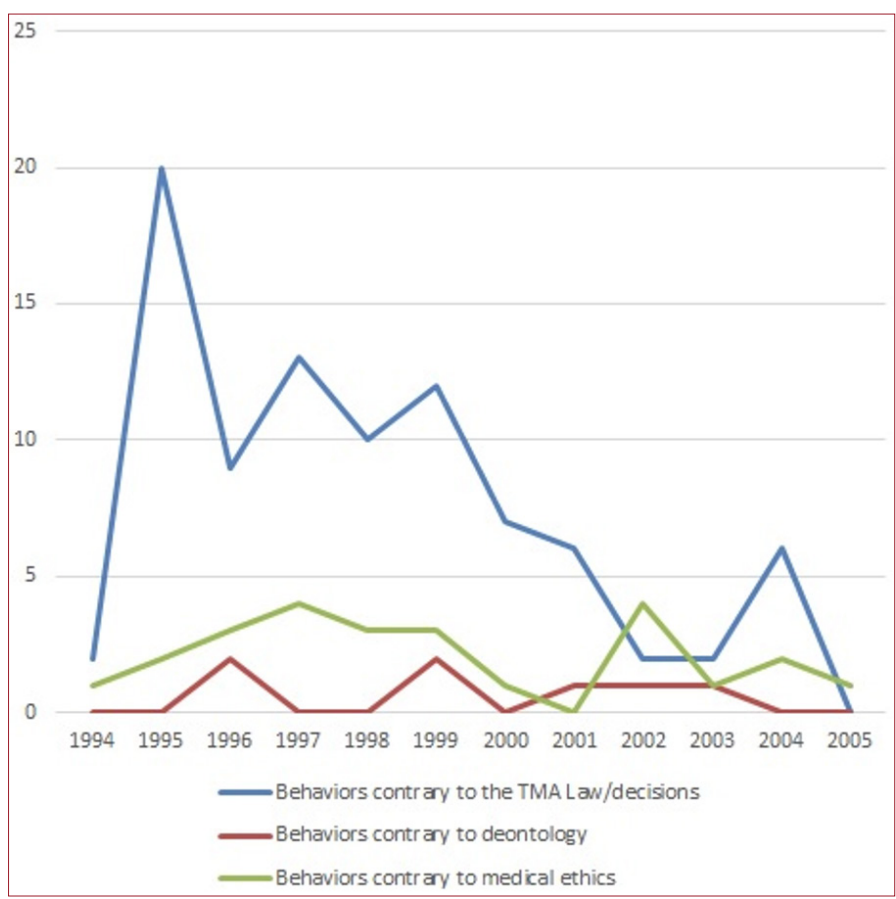

Figure 3. Reasons for complaints by year

Table 4. Distribution of complaints according to the general characteristics of the cases

\begin{tabular}{|c|c|c|c|c|c|}
\hline & & $\begin{array}{l}\text { Behaviors contrary to the Turkish } \\
\text { Medical Association Law/decisions }\end{array}$ & $\begin{array}{l}\text { Behaviors contrary to } \\
\text { deontology }\end{array}$ & $\begin{array}{l}\text { Behaviors contrary to } \\
\text { medical ethics }\end{array}$ & p \\
\hline \multirow{4}{*}{ Complainant } & Medical Chamber & $50(89.3 \%)$ & $2(3.6 \%)$ & $4(7.1 \%)$ & \multirow{4}{*}{$<0.001$} \\
\hline & Physician & $18(72 \%)$ & $3(12 \%)$ & $4(16 \%)$ & \\
\hline & Patient and relatives & $1(6.7 \%)$ & - & $14(93.3 \%)$ & \\
\hline & Other & $20(80 \%)$ & $2(8 \%)$ & $3(12 \%)$ & \\
\hline \multirow{3}{*}{ Penalty } & No need & $11(44 \%)$ & $2(8 \%)$ & $12(48 \%)$ & \multirow{3}{*}{$<0.001$} \\
\hline & Fines & 65 (94.2\%) & $2(2.9 \%)$ & $2(2.9 \%)$ & \\
\hline & Banned from profession & $6(50 \%)$ & - & $6(50 \%)$ & \\
\hline \multirow{3}{*}{$\begin{array}{l}\text { Decision of Honor } \\
\text { Board }\end{array}$} & No need & $8(33.3 \%)$ & $2(8.3 \%)$ & $14(58.4 \%)$ & \multirow{3}{*}{$<0.001$} \\
\hline & Warning & $6(54.5 \%)$ & $2(18.2 \%)$ & $3(27.3 \%)$ & \\
\hline & Fines & 68 (94.4\%) & $2(2.8 \%)$ & $2(2.8 \%)$ & \\
\hline \multirow{2}{*}{$\begin{array}{l}\text { Reasons for } \\
\text { transmission to } \\
\text { High Honor Board }\end{array}$} & Physician objection & $27(81.8 \%)$ & $2(6.1 \%)$ & $4(12.1 \%)$ & \multirow{2}{*}{0.005} \\
\hline & Other & $3(33.3 \%)$ & - & $6(66.7 \%)$ & \\
\hline \multirow{2}{*}{$\begin{array}{l}\text { Decision of High } \\
\text { Honor Board }\end{array}$} & Approval & $21(75 \%)$ & $2(7.1 \%)$ & $5(17.9 \%)$ & \multirow{2}{*}{0.816} \\
\hline & Reversal & $7(70 \%)$ & - & $3(30 \%)$ & \\
\hline
\end{tabular}


The total decisional time of the BMC HB was between 6.5 (171.5) months. The decision periods of the cases complained for the behaviors contrary to the TMA Law / decisions 5 (171.5 months) was determined to be more than the decision periods of behaviors contrary to deontology 9.5 (3.5-21.5 months) and the behaviors contrary to medical ethics 9.5 (1.5-24.5 months). When the decision periods were examined in terms of penalties, it was determined that the decision periods were less in cases where warning penalties 6.5 (1.59.5 months) were given than the decision periods in cases where money 4.5 (1-71.5 months) and ban from profession 10.75 (4.5-33.5 months) penalties were given $(p=0.001)$.

When BMC HB decisions and TMA HHB decisions were examined in cases in terms of the reasons for transmitted to TMA HHB, it was found that there was a physician objection with a rate of $95.8 \%(n=23)$ in cases where fines were given $(p<0.001$, Table 5 ). $92.9 \%$ of TMA HHB decisions in the cases submitted with a physician's objection were approved by TMA HHB $(p=0.008)$. When the approved decisions were examined, it was determined that $100 \%(n=10)$ of the decisions were approved for being banned from the profession; $70.8 \%(n=17)$ of the decisions were approved for fine and $50 \%(n=1)$ of the decisions were approved for warning $(p=0.001)$.

Table 5. Reasons for transmission to High Honor Board according to the decisions of BMC HB and TMA HHB

\begin{tabular}{|c|c|c|c|c|}
\hline & & \multicolumn{2}{|c|}{$\begin{array}{c}\text { Reasons for transmission } \\
\text { to High Honor Board }\end{array}$} & \multirow{2}{*}{$\mathbf{p}$} \\
\hline & & $\begin{array}{l}\text { Physician } \\
\text { objection }\end{array}$ & Other & \\
\hline \multirow{4}{*}{$\begin{array}{l}\text { Decision of } \\
\text { Bursa Medical } \\
\text { Chamber } \\
\text { Honor Board }\end{array}$} & No need & - & $5(100 \%)$ & \multirow{4}{*}{$<0.001$} \\
\hline & Warning & $2(66.7 \%)$ & $1(33.3 \%)$ & \\
\hline & Fines & $23(95.8 \%)$ & $1(4.2 \%)$ & \\
\hline & $\begin{array}{l}\text { Banned from } \\
\text { profession }\end{array}$ & $8(80 \%)$ & $2(20 \%)$ & \\
\hline \multirow{2}{*}{$\begin{array}{l}\text { Decision } \\
\text { of Turkish } \\
\text { Medical } \\
\text { Association } \\
\text { High Honor } \\
\text { Board }\end{array}$} & Approval & 26 (92.9\%) & $2(7.1 \%)$ & \multirow[b]{2}{*}{0.008} \\
\hline & Reversal & $5(50 \%)$ & $5(50 \%)$ & \\
\hline
\end{tabular}

\section{DISCUSSION}

The medical chamber is a professional association authorized to evaluate the behavior of physicians practicing their profession in violation professional law, morality and/or ethics and to impose disciplinary punishments if necessary. ${ }^{[9,10,15]}$ In addition to the studies conducted in the medical chambers in which the investigation and prosecution files were examined ${ }^{[7,12-14,16]}$ the violations in the files discussed at the Supreme Health Council and the TMA HH ${ }^{[1,17-22]}$ were also investigated. This study was planned to examine the files of the honor board of the medical chamber in Bursa, the fourth largest city of Turkey.
It was found that the vast majority of the physicians who complained were specialists ( $n=75,67.6 \%)$. It was considered that this is due to the fact that specialist physicians can work in public institutions, as well as private hospitals, polyclinics and private practice. In addition, the fact that public employees did not have to register in the chamber may explain the excess in the number of specialist physicians. General surgery and obstetrics and gynecology took priority in their areas of expertise, and this result is in line with other studies. $[7,11,12,16,17,20-24]$ The reasons for the high rate in two areas could be intervention in the body, consequences that may affect the quality of life, openness to possible complications and errors, etc.

When the files were evaluated in terms of the complainants, a high rate of the administrative board (46.3\%) was found in parallel with the other studies. ${ }^{[11,12,14]}$ Although it was seen that the complaints of patients and their relatives started to increase in the studies conducted by Civaner, ${ }^{[12]}$ Öztürk et al. ${ }^{[13]}$ and Akyol et al. ${ }^{[14]}$ the complaints of the patients and their relatives were very few in our study. Even though it was predicted that patient complaints would increase with the right of complaint (Art. 42) defined by "Patient Rights Regulation"[25] in 1998, other studies also found higher rates of medical chamber complaints, as in our study. It was thought that this situation was caused by reasons such as the patients' lack of awareness of complaints, the fact that the disciplinary process of the physicians working in the public sector is carried out independently of the medical chambers, and the medical chambers are considered secondary in violations of medical ethics. Although the complaints were expected to increase with the "Patient Rights Regulation", the distribution between years was also inconsistent with the difference between the years investigated in other studies. ${ }^{[7-10]}$

Considering the reasons for complaints in the files, behaviors contrary to TMA Laws/decisions are seen in the first place (73.5\%). This result is consistent with the studies conducted by Civaner et al..$^{[11]}$, Öztürk et al. ${ }^{[13]}$ and Akyol et al. ${ }^{[14]}$ Under this main heading it was found that "promotion for advertising purposes" ranked as $40.5 \%$ and this result was also found to be compatible with other studies. ${ }^{[7,12,14]}$ Reasons such as increasing competition with the number of physicians, not knowing what to pay attention to when preparing signage to reach more patients could be the reasons for this high rate. $[7,26,27]$

In the statistical analysis between the causes of complaints and age, it was found that the physicians who exhibited behaviors contrary to the TTB Laws/decisions were younger and the physicians who exhibited behaviors contrary to medical ethics were older $(p=0.001)$. This could be considered as the fact that physicians who have just started their profession do not know enough about the legislation, while elderly physicians do not have courses on medical ethics during their education.

Considering the penalties according to the reasons for the complaint, it was found that $94.4 \%$ of them were imposed 
fine for the behaviors contrary to the TMA Law/decisions. Due to the physician's objection to the punishment given, the decision was forwarded to TMA HHB and it was concluded that all of the approved files were fines. Of the 42 files forwarded TMA HHB, $81.8 \%$ were because of the behaviors to the TMA Laws/decisions and $51.3 \%$ of them were fined. While this result reached the same result as the study conducted by Akyol et al. ${ }^{[14]}$ it was seen that the most common punishment for being banned from the profession in the study conducted by Civaner et al..$^{[1]}$

Considering the completion/determination periods of the reviewed files, it was seen that notification was generally made within 1-71.5 months. Considering the reasons for the complaint, it was found that the files investigated for the longest period of time due to the behaviors contrary to the TMA Laws/decisions; considering the punishment given, it was found that the longest period was in fines. This statistically significant result is in parallel with the results of Civaner et al. ${ }^{[11]}$

\section{CONCLUSION}

Institutions such as medical chambers, Local Health Authorities, Institution of Forensic Medicine, Supreme Health Council play an important role in the investigation/ prosecution of problems encountered in professional practices. Among these institutions, medical chambers can reach a decision on the physicians who are the subject of the complaint by conducting investigations / prosecutions within the framework of the authorities granted to them by law. ${ }^{[9,10]}$ There are studies in which physicians were complained in different cities, the reasons for the complaints and the punishments given are studied. ${ }^{[7,11-14,16-22]}$ In particular, the fact that physicians working in public institutions do not have to be members of the medical chamber and that not every complaint goes to the honor boards is an important limitation in making a comment in general.

As shown by the files analyzed and supported by other studies, it seems that the vast majority of physicians who cause complaints are investigated and mostly fined for behaviors contrary to TMA Laws/decisions and behaviors contrary to deontology. This result is mostly seen due to the physicians' ignorance of the legislation. However, the fact that physicians' ignorance of the legislation is not accepted as an excuse reveals the necessity of knowing the responsibilities of physicians and shows the importance of deontology and medical ethics education in pre- and postgraduate education.

Examining the investigation/prosecution files is an important resource both in discussing the effectiveness of medical chambers and in determining where physicians make the most mistakes. For this reason, conducting such researches and conducting discussions in different media will be the leading criteria in terms of making updates in the education and practice of the medical profession.

\section{ETHICAL DECLARATIONS}

Ethics Committee Approval: The study was carried out with the permission of Uludağ University Faculty of Medicine Medical Research Ethics Committee (Number: 2005-7/13).

Informed Consent: Because the study was designed retrospectively, no written informed consent form was obtained from patients.

Referee Evaluation Process: Externally peer-reviewed.

Conflict of Interest Statement: The authors have no conflicts of interest to declare.

Financial Disclosure: The authors declared that this study has received no financial support.

Author Contributions: All of the authors declare that they have all participated in the design, execution, and analysis of the paper, and that they have approved the final version.

Note: The study was produced from the doctoral thesis titled "Bursa Tabip Odası Onur Kurulu Dosyalarında Tıp Etiği Sorunlarının Değerlendirilmesi"

Acknowledgements: We would like to thank the BTO management who provided significant support in the conduct of the study and the chamber staff, especially Saliha Dülger.

\section{REFERENCES}

1. Gökçe AN. İstanbul Tabip Odasının Tarihçesi. Ayyıldız Matbaası: İstanbul; 1996.

2. Ünver AS, Şehsuvaroğlu NB. Türkiye'de Tıbbi Cemiyetler Tarihçesi. Yeni Türkiye Basımevi: İstanbul; 1956.

3. Ünver AS. Cemiyeti Tıbbiyei Osmaniyenin Eyüp'teki Yeri. Türkiye Tıp Encümeni Arşivi 1947;1(3):87-8.

4. Artunkal S. Türkiye Tıp Akademisi'nin Tarihçesi. Türkiye Tıp Akademisi Mecmuası 1968;3(1):3-12.

5. Sayek F. Türk Tabipleri Birliği "Tarihe Giriş". Türk Tabipleri Birliği Merkez Konseyi: Ankara; 1998.

6. Arar A. Etıbba Odaları. Modern Tedavi Mecmuası 1951;1(3):65-6.

7. Başağaoğlu İ. İstanbul Tabip Odasına İntikal Eden Etik Sorunlar. In: Hatemi H, Doğan H, editors. Medikal Etik-2. İstanbul: Yüce Yayım; 2000. pp.67-89.

8. Eskiocak M, Saltık A, Tuncay Ç. Tabip Odaları ve Temel Sağlık Hizmetlerinin Desteklenmesi. Toplum ve Hekim 2000; 15(4): 301-5.

9. Türk Tabipleri Birliği Kanunu. RG: 31/1/1958 tarih ve 8323 sayı.

10. Türk Tabipleri Birliği Disiplin Yönetmeliği. RG: 28.04 .2004 tarih ve 25446 sayı.

11. Civaner M, Okuyan AZ. Türk Tabipleri Birliği Yüksek Onur Kurulu Dosyalarında Tıbbi Etik İhlalleri. Türk Tabipleri Birliği: İzmir; 1999.

12. Civaner M. Disciplinary committee files of a metropolis' medical association. Turkiye Klinikleri Journal of Medical Ethics-Law and History 2002;10(3): 202-13.

13. Öztürk H, Arda B. Ankara Tabip Odası́nın 1995-1996 Dönemindeki Soruşturma Dosyalarıyla İlgili Analitik Bir Çalışma. In: Pelin SŞ, Arda B, Özçelikay G, Özgür A, Çay F, editors. III. Tıbbi Etik Sempozyumu Bildirileri. Ankara; 1998. pp. 365-8.

14. Akyol IU, Yücesoy A. Antalya Tabipler Odası 1996-2001 Yılları Arasında Onur Kuruluna Sevk Edilen Dosyaların İncelenmesi. Toplum ve Hekim 2002;17(5):379-84.

15. Hancı İH. Malpraktis. Tıbbi Girişimler Nedeniyle Hekimin Ceza ve Tazminat Sorumluluğu. Seçkin Yayıncılık: Ankara; 2005.

16. Yücel R, Şendağ N, Doğan İ. İstanbul Tabip Odası Hekimlik Uygulamaları 2001 - İstatistik Yıllığı. In: Hatemi H, Doğan H, editors. Medikal Etik-4. İstanbul: Yüce Yayım; 2002. pp.76-99. 
17. Gündoğmuş ÜN, Ersoy N, Biçer Ü. Yüksek Sağlık Şurası Kararlarının Etik Açıdan Değerlendirilmesi. In: Pelin SŞ, Arda B, Özçelikay G, Özgür A, Çay F, editors. III. Tıbbi Etik Sempozyumu Bildirileri. Ankara; 1998: 351-64.

18. Özkara E, Naderi S, Gündoğmuş ÜN, Arda N. Evaluation of Cases of Spine Surgery Malpractice Discussed Between 1994 and 1998 in High Health Council. Türk Nöroşirurji Dergisi 2004; 14(3):151-7.

19. Türkan H, Tuğcu H. Malpractice Cases Related with Emergency Medicine, Evaluated by Supreme Council of Health Between 2000-2004. Gülhane Tıp Dergisi 2004;46(3): 226-31.

20. Gündoğmuş ÜN, Erdoğan SM, Şehiraltı M, Kurtas Ö. A Descriptive Study of Medical Malpractice Cases in Turkey. Ann Saudi Med 2005; 25(5): 404-8.

21. Tümer AR, Dener C. Evaluation of Surgical Malpractice in Turkey. Legal Medicine 2006; 8(1): 11-5.

22. Gündoğmuş ÜN, Bilge $\mathrm{Y}$, Kendi Ö, Hancı IH. Hekimlerin yasal sorumluluğunun yüksek sağlık şurası açısından irdelenmesi. Adli Tıp Bülteni 1997; 2: 127-30.

23. Büken E, Büken NÖ, Büken B. Obstetric and Gynecologic Malpractice in Turkey: Incidence, Impact, Causes and Prevention. Journal of Clinical Forensic Medicine 2004; 11(5): 233-47.

24. Shah P, Shuren WA. The Current Medical Malpractice Environment: An Analysis of Causes and Solutions. Journal of Pediatric Health Care 2005; 19(2): 112-6.

25. Hasta Hakları Yönetmeliği. 01.08.1998 tarih ve 23420 sayı.

26. Arıkan A. Hekim İlanları ve Tanıtım (Reklam ve Tabela) Etiği. In: Pelin SŞ, Arda B, Özçelikay G, Özgür A, Çay F, editors. III. Tıbbi Etik Sempozyumu Bildirileri. Ankara; 1998: 199-215.

27. Dinççağ ME. Reklam ve Hekimlik. Toplum ve Hekim 1994; 9(63): 4-5. 